\title{
A Note on Resistance to Flow of Viscous Fluid.
}

\section{K. Suyehiro, Member.}

'This problem has been studied thoroughly by many celebrated investigators such as Kelvin, Rayleigh, Osborne Reynold, Froude, and Stanton, some of them from purely scientific aspects and the others from practical roints. Nevertheless, owing to the complicated nature of the phenomena, there are still ample field for further exploration. This short no'e is only a trifling speculative view, but may not be valueless for thoze interested in the pesent subject.

In the course of experimenting on the turbulent flow of a thin fluid stratum, HeleShaw ${ }^{(1)}$ observed that a fine clear border appeared along the walls and therefrom concluded that within this border the parallel flow of water existed. Stanton ${ }^{(2)}$ also remarked the existence of the layer of lamina: flow at the boundary of fluid in turbulent flow from the evidence foind in his experimental researches.

To see how such a zone of stable flow is related to the velocity of the flow of fluid, the author made an experiment after the me!hod originated by Hele-Shaw. Water fed to a tank with over-flow arrangement (to keep the pressure constant) is led to a close space between purallel glass plates through a flat circular distribating reservoir having the inlet opened at the centre and the outlets arranged symmetrically around the circumferencial will. The width of the thin water channel between the glass plates is made 13 cm. and the thickness $0.137 \mathrm{~cm}$. 'To detect the nature of the flow across the width of the channel, coloured water is fed at the inlet side of the channel through pin holes pierced in a flat square pipe, the uppor surface of which is in tire plane of tho inside surface of the lower glass p'ate. 'The pin holes have a uniform pitch of $0.5 \mathrm{~cm}$. and the outermost ones are just close to the side wall of the channel; thus 27 coloured bands flow with the

(1) H. S. Hele-Shaw "Experiment ou the nature of thy surface resistance in pipes and on ships" Tran. I. N. A. Vol. 39 (1\&97)

(2) T. E. Stanton "Fricion" Dictionary of Applied Thysics Vol. I. 
water to show the nature of the motion and are photographed by a camera fitted over the glass plates. The general arrangem nnt of the apparatus is shown in Fig. 1.

First, to study the feature of stable flow within the stream line apparatus, the mean speed of flow was kept very low and by giving a siries of slight shocks on the indiarubber feed pipe connected to the coloured liquid tank, the f.ont lines of the flow were obtained. Fig. 2 shows a photograph of such front lines when the mean speed of flow was $8.22 \mathrm{~cm} . / \mathrm{sec}$. It will be seen that the speed is distributed ne urly parabolic.

A similar photograph when the speed just exceed d the stable range (mean speed $=47.00 \mathrm{~cm} . / \mathrm{sec}$.) is shown in Fig. 3. It will bə se.n that, although a slight turbulence now , appeared, yet the speed distribution had not much difference compared with the previous case.

In increasing the speed still further, the turbulence increased more and more; the tarkulence first starting at the middle part and spreading by and by to the sides as the speed increased. This fact can be seen from Fig. 3 to 7 , the numbers of which: are in the order of the speed (namely Fig. $4: 55.0$ cm./sec., Fig. $5: 59.0$ cm./sec., Fig. 6: $79.4 \mathrm{~cm} . / \mathrm{sec}$. , and Fig. $7: 81.8 \mathrm{~cm} . / \mathrm{sec}$.) This spreading-out of the turbulence may. perhaps due to the fact that, as the flow is limited within a uniform narrow space and: the speed is the faster the nearer to the middle line "is, the critical speed which is. related to the thickness of stream is first exceeded on the midelle line and thus turbulent motion begins at the middle portion and gradually spreads out to the sides as the speed of fiow increases. This turbulence does not, however, proceed to the wall, and it is likely that there exists a band of stable flow along each side wall, however quick the mean speed of flow is. This can be seen by the naked eye even when the speed of flow is very high; notwithstanding the coloured liquid is diffused into the water as soon as it leaves the pin holes, one band just close to each side wall retains its colour (Figs. 6 and 7 nearly show this feature).

It is likely that the flow just close to the walls remains to be steady in so far as the mean speed over this stable range does not excesd the critical speed which will have a fixed value for the breadth of the steady stream as well as the distance: between the glass plates; the breadth of the steady border may narrow as the 'speed 
increases. Thus the breadth of the steady border will be self-adjusting, to accord with the velocity of flow.

It is questionable whether we may push this inference to the case of three dimensional turbulent flow in a pipe. Although for obvious reasons such an experiment cannot be carried out with equal success in the case of three dimensional flow, the author found that a similar plenomenon existed even in the case of flow in a pipe. 'To see the phenomen $>n$, an experiment after Osbrime Reynold's method was made with a slight modification that in the present case the glass pipe was held vertic ılly and two coloured liquid filaments were led into the pipe, cne at the centre and the other close to the wall in a manner as shown in Fig. 8.

It was found that the stability of flow first dest oyed at the centre, and even after the filament at the centre wholly disappeared that by tho wall still existed, spreading closely along the wall of the pip 3 just like a curtain. Though the author could not ascertain by this experiment whether a stable border adhered on the wall at all speods in a manner as in the case of two-dimensional flow, yet more stability nea: the wall seems to justify the author's view that self-xdjusting stable range exists along the wall.

The stable flow in a pipe is shown in Fig. 9 in which the centre filament (appears as a straight line), as well as the flow along the wall (seems like a curtain covering nearly one quarter of the total a:ea) can clearly be seen. Fig.10 shows the flow when at an increased speed the centre filament was no more existing but the curtain-like stable flow near the wall still persisting.

According to this view, we may calculats the resisitance of flow in a pipe in a following manner. It was shown by $\mathrm{Orr}^{(1)}$ that in the case of uniform shearing motion between parallel planes one of which is at rest and the other moving with a velocity $\boldsymbol{u}_{0}$, the critical velocity is given by

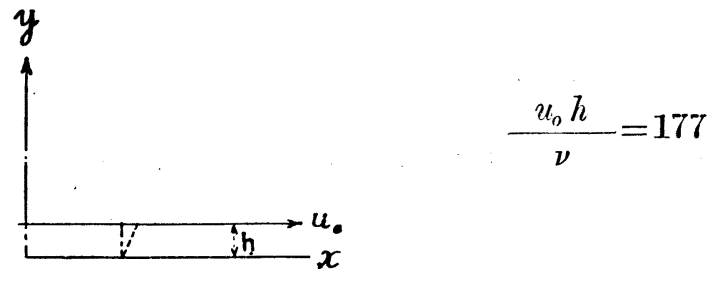

(1) Rayloigh "Collected Papers" VI, Page 266. 
in which $h$ is the distance between the parallel planes, and $\nu$ the kinematic viscosity $\frac{\mu}{\rho}$.

Also Reynold(2) proved that, where there is a flow varies as $h^{2}-y^{2}$ parallel to $x$ between two fixed plane $y= \pm h$, the critical ratio is given by

$$
\frac{\bar{u} h}{\nu}=258
$$

in which $\bar{u}$ is the mean speed. Now, if $u_{0}$ is the maximum speed on the middle line,

$$
u_{o}=\frac{3}{2} \bar{u}
$$

Therefore, the above exp:ession may be written,

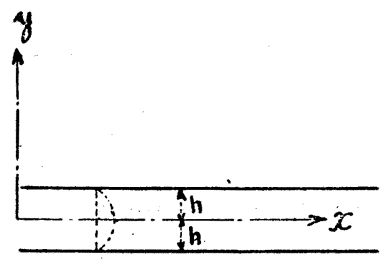

$$
\frac{u_{0} h}{\nu}=387
$$

We are not in a position to discuss whether in the stable region the flow is a uniform shearing motion or of a motion expressible by a parabolic equation. Be that as it may, in the for.xer case as $u=\frac{u_{0}}{h} y$, the viscous resistance offered by tine wall is given by

$$
R_{y=0}=\mu\left(\frac{\partial u}{\partial y}\right)_{y=0}=\mu \frac{u_{0}}{h}
$$

In the latter case, as $u=u_{0}\left(1-\frac{y^{2}}{l^{2}}\right)$, the same resistance is given by

$$
R_{y=-l}=\mu\left(\frac{=u}{\partial y}\right)_{y=-h}=2 \mu \frac{u_{3}}{h}
$$

Now Orr's critical number gives

$$
h=\frac{177}{u_{0}} v \ldots \ldots \ldots \ldots \ldots \ldots \ldots \ldots \ldots \ldots \ldots \ldots \ldots
$$

while Reynold's number

$$
h=\frac{387}{u_{o}} \nu
$$

Substituting (a') and $\left(b^{\prime}\right)$ into (a) and (b) respectively, we have

$$
R=\frac{1}{177} \rho u_{0}^{\circ}
$$

(2) Osborno Reynold "Scientific Paper" II, Fig 375. 
and

$$
\mathbf{R}=\frac{1}{194} \rho u_{0}^{2}
$$

We are not able to find how the value of $u_{o}$, the maximum speed in the stable region is related to the mean speed of the turbulent flow. It will be worth mentioning, however, that in either case the resistance deduced gives the same order of magnitude as that given by a well known formula for the resistance of turbulent flow in a motallic pipe, namely $R=\frac{1}{400} \rho V^{2}$ in which $V$ is the mean velocity of flow.

The auther has to express his indebtedness to the Kondo Marine Research Assets for the grant of the expense of the present experiment.

\section{討 論}

○官長代理主事(藤岛範平君）會長は餘義ない用事の焉に退席いたされましたので、暫く本席を 污します。唯今の御講演に對し御質間又は御意見がありますれば御述べにならむてとを願ひます...... 如何ですか。どなたか「レジスタンス」專門の御方も見えて居りますやうでありますが……

○重光簇君 私は光生の御講演に對しまして、まだ了解いたしても居りませぬし、之に付て彼是云 ふやらな考は毛頭ないのでありますが、「レジスタンス」の方から、此摩摖抵抗と云ふ閌題が、今日ま だ解決せられない第に、如何に私共が困つて居るかと云ふ現状を無論先生は御承知のてとででさいま すが、台瓜先生は「レジスタンス」の方に餘り興味を持たないと云ふ御活でありましたけれども御始 めになりましたてとでありますからして、どうか将來も引續いて御研究を願ひまして、我々が困つて 居る問題に解決を與へて戴きたいと思ひます、御承知の通りに「レジスタンス」の方から廣く使はれ て居りますのは「フルード」の式であります。此式を使つて勘起した絬果は。英吉利に於ては長い船 「ハイスピード」の船に對しては、稍く「オーバーエステイメーション」になるのではなかららかと 云ふやらなてとを申して居るやうであります。所が亞米利加で使つて居ります式によれば。抵抗は「 ルード」の式に依るよりも多く出る。而して之に對しては多く出るから之を使ふと云ふ說明が附いて 居ります。文困つた問題は。闹じ式を使ひましても「モデル」の大きさに伥つて同じ船の「レジスタ ンス」が違つて出て來るのではないかと思はれます。斯樣な工合に色々區々な意見があり。銘く自分 の所のj法が事贔に合ふと主㖘して居ります。其上に從來は板のやうな場合は「レジスタンス」の 「インテンシテイ」が板の前部の方は大きく後部に行くに從て炏第に小さくなるやらに考へられて居 りますが、「スタントン」の貫驗では、空乘中の䨘驗でありますが、此は殆んど「コンスタント」のや

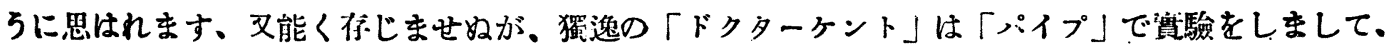
矢张「インテンシテイ」は長さに依つてさう變化しないと云ふてとを云つて居ります、斯栐なエ合で 
あるとしますと、抵抗は今までの勘定の方法よりる多少多く出て杫るのではなかららか「ケント」は 右の實驗結果により抵抗が多くなる樣な式を作つて、それが顠際に大變能く合ふと云ふやらなてとを 云つて居るさらであります、斯樣な工合に要するに種々㥞々の說があり。さらしで是に斷定を與へる てとの出來ない、それだりの能力のないものに取りましては、どれに從つて宜いのか、殆ど見當が着 かないのであります。幸に未廣先生が此問題を御始め下さいましたですからして、に゙うか今後も䌡續 して御研究を願ひまして、之に斷案を御與へ下さいまして、我々に向ふ所を御示し下さらむてとを乔 残する次第であります、ちよつと御禮旁々希然を述べます

○末廣恭二君 重光さんに御答いたしますが、重光さんから大變な御推稃を得ましたが、私は其任 でもございませぬのみならず、之をやりましたのは「ローリング」に對する裴面抵抗を調べて居て一

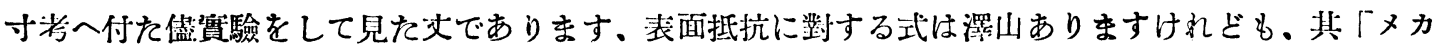
ニズム」を論じたものは餘り檌山は無い樣であります、ブラジド」などの芌による、極めて「サーフ エース」に近き水は「ローリング」見たいな運動をして居るといふ事はあるべきてとら゙やない樣に思 はれます、私は今少しく自分で滿足し得る「メカニズム」を若へて見たいと思つて、唯てんな考を出 して見ましたので、此「メカニズム」が果して宜いか惡いか。自分ですらまだ確信は焎いのでありま す、此難かしい問題を明快に解く事などは私は其任ではでざいませ双。尐战重光さん御自身に於て大

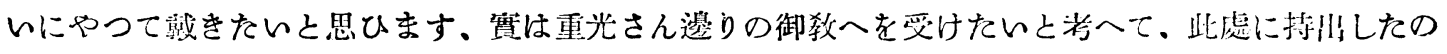
であります。

○會長代理主事(藤島範平君) 外に御發言もないやうでありますから、私より一高御禮を中述べ

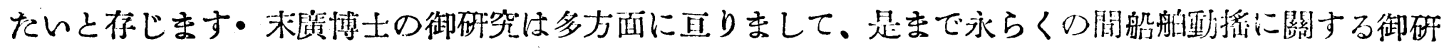
究を續けられ。常に其結果を本會に御發表になつて鬼られますが。份又此度は新しき「バランシング マシーン」に付て御發明になりましたてとを御發表になりまして、今又御自身から承る所に低ります れば、新をに「ハイドロ.ダイナミツクス!の方に乎を染められまして、御研究になつて㕍るとのてと

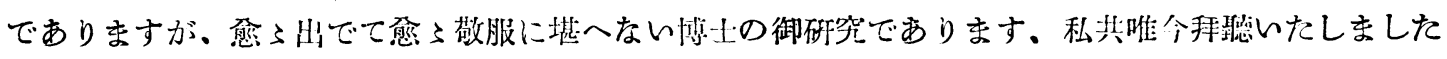
だけでは、ビうも餘りに高遠な理論でありまして、「フォロー」するてとが川來ませ如のでありますが

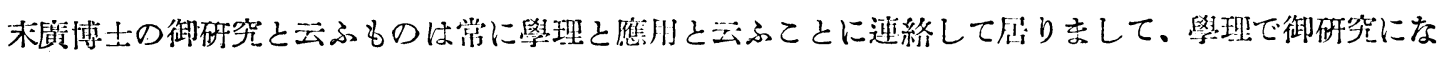

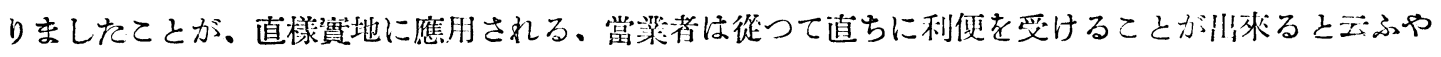
ろに、是までの御研突が行つて居るのでありまして、此摩擦抵抗の御研笔も、唯今御話になりました

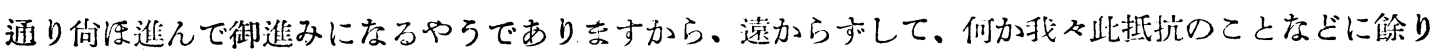
知識のない者も能く了解が出來て、さらして直ぐ役に立つと云ふやらなものを御示し下さる時期があ

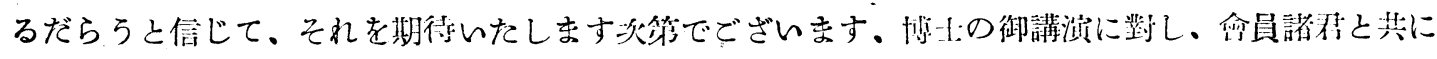
拍手を以て敬意を裴したいと保じます。（一同拈手） 




Fig. 1.

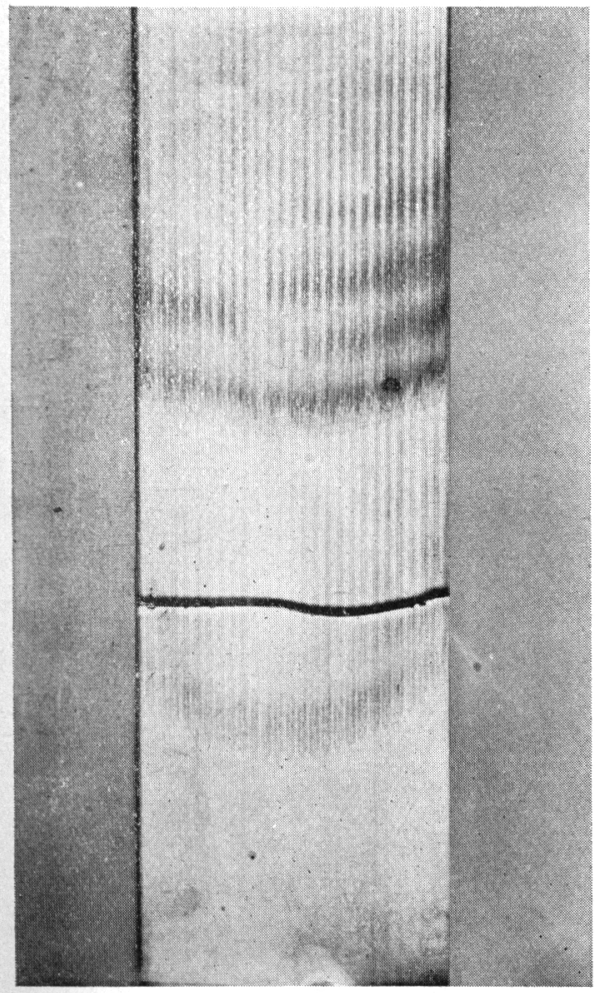

Fig. 2.

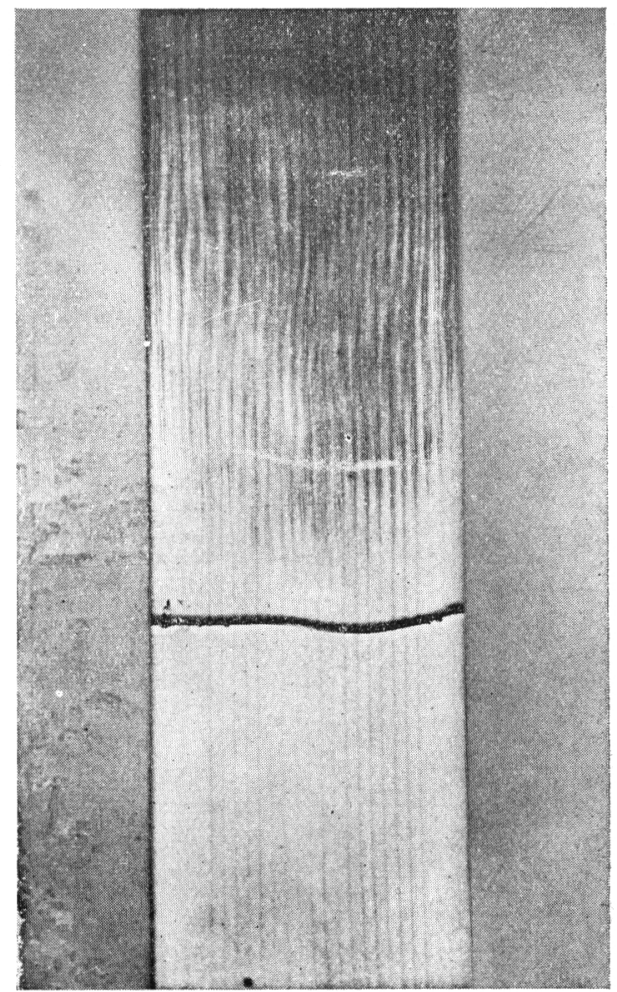

Fig. 3. 


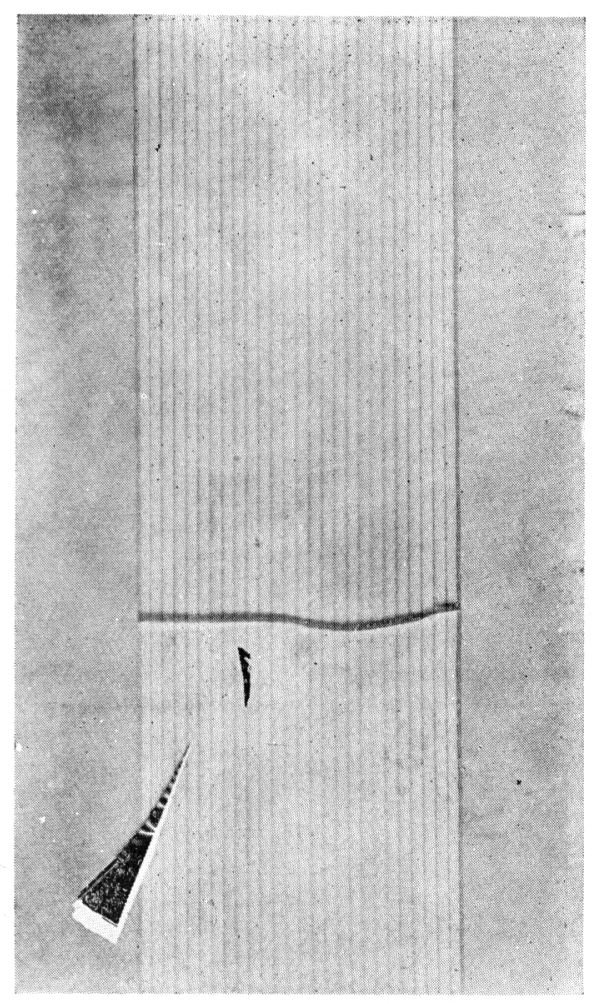

Fig. 4.

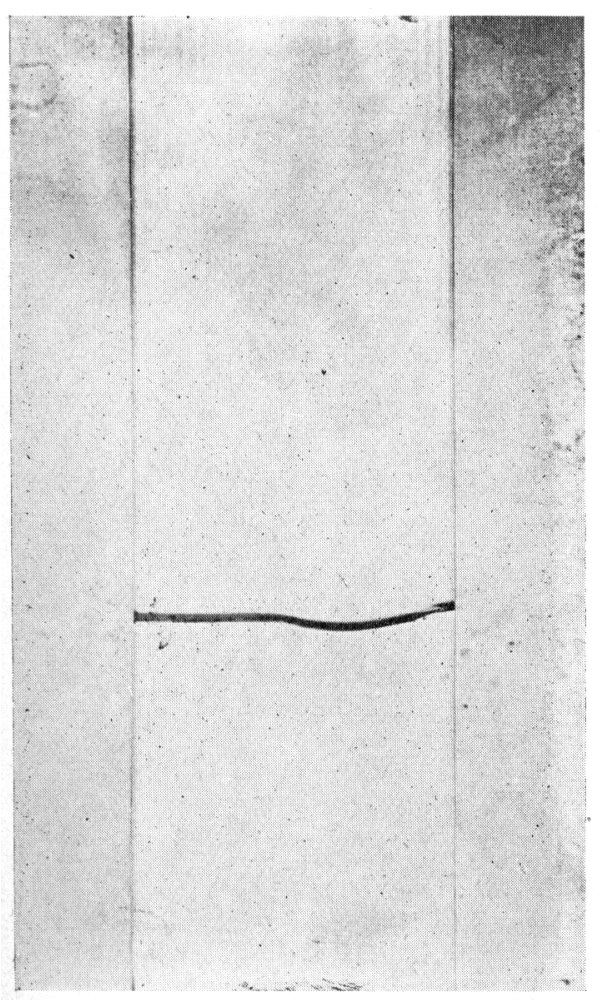

Fig. 6.

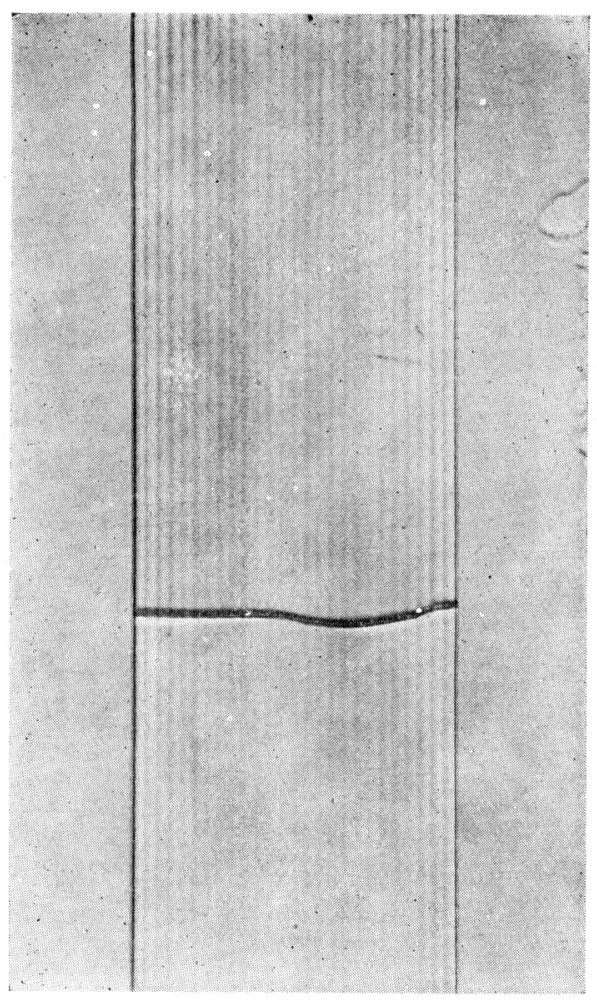

Fig. 5.

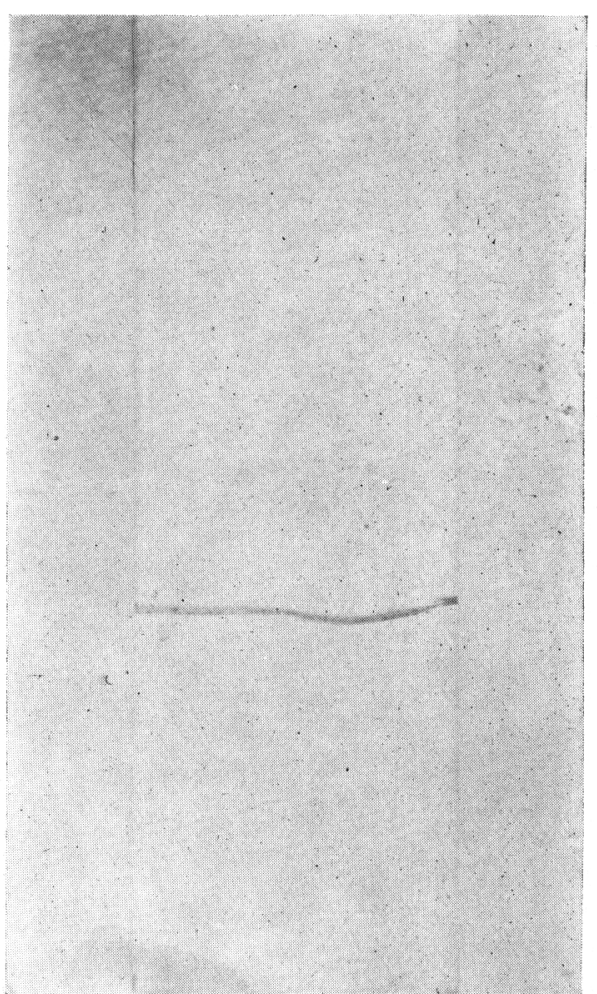

Fi⿱夂. 7. 


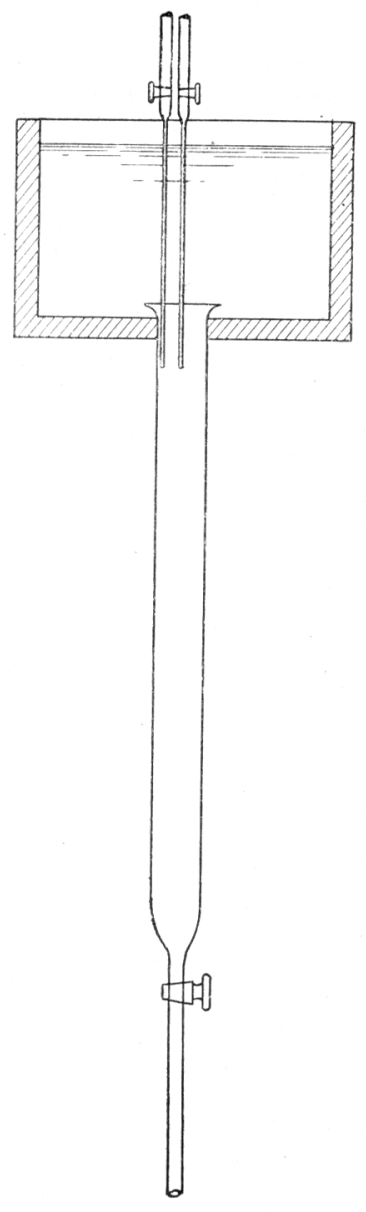

Fig. 8.
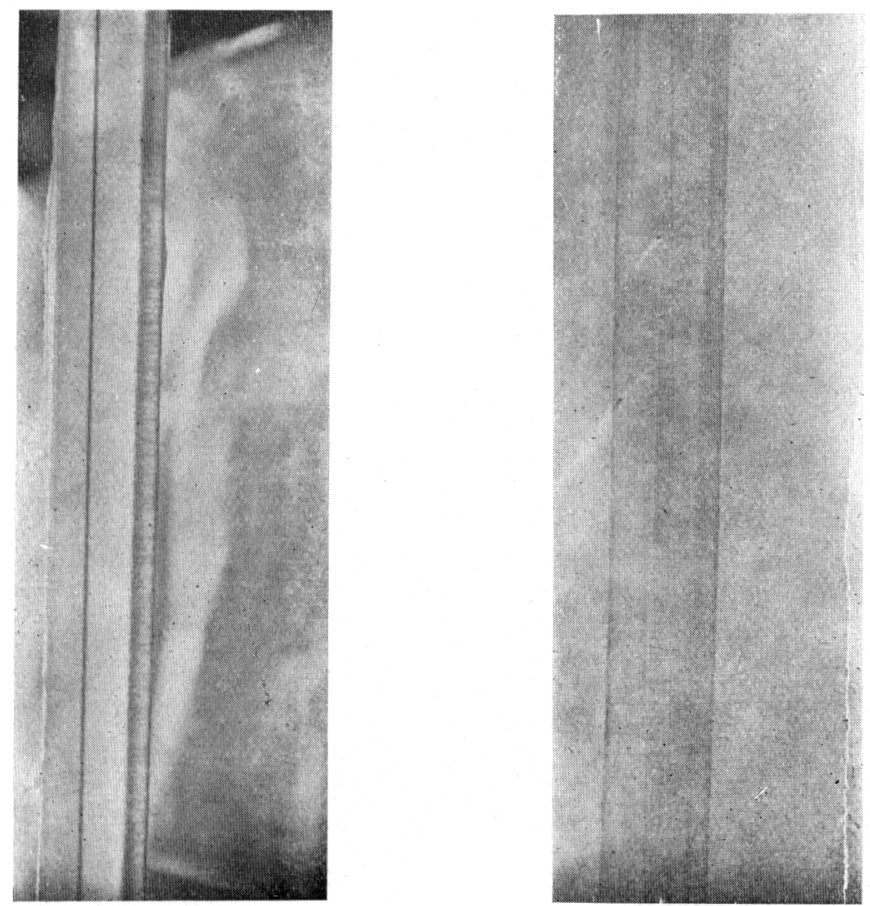

Fig. 9.

Fig. 10. 